\title{
STABLE MUSCLE RELAXATION DURING ABDOMINAL SURGERY USING COMBINED INTRAVENOUS BOLUS AND DEMAND INFUSION: CLINICAL APPRAISAL WITH ORG NC45
}

\author{
A.A. D’Hollander, R. Czerucki, A. Deville and F. Cuvelier
}

\begin{abstract}
In order to obtain stable muscle relaxation for intra-abdominal operation, a continuous demand perfusion of ORG NC45 was administered following a loading dose of $0.07 \mathrm{mg} \cdot \mathrm{kg}^{-1}$. The patients had previously been anaesthetized with inethohexitone, fentanyl and nitrous oxide. The perfusion rate of ORG NC45 was regulated so that the mechanical muscular response of the adductor pollicis following a supra-maximal stimulation of the ulnar nerve was maintained at 10 per cent of its initial value. The level of relaxation thus obtained was always adequate for the surgeons. During the course of the operation the requirement for more relaxant decreased progressively, becoming stable after one half hour. Nevertheless, during stable administration, individual variations were quite marked, being 44 to $483 \mu \mathrm{g} / \mathrm{M}^{2} \mathrm{BSA} / 10 \mathrm{~min}$ (average $225 \mu \mathrm{g} / \mathrm{M}^{2} \mathrm{BSA} / 10 \mathrm{~min}$ ). The duration of the infusion varied from 60 to 107 minutes (average 103 minutes). After its termination the time taken from recovery varied between 3 and 82 minutes (average 27 minutes). Having regained a single twitch height of 75 per cent patients awoke rapidly after the administration of nitrous oxide was terminated. No signs of recurarization were noticed in any of the patients.

In conclusion, this method of administration of ORG NC45 assures a stable level of curarization without side-effects. However, because of the different individual levels of sensitivity which were noted, this mode of administration requires careful monitoring to avoid inappropriate dosage.
\end{abstract}

KeY Words: NeUROMUSCULAR Relaxants, non-depolarizing; ORG NC45.

\section{INTRODUCTION}

OF ALL THE different branches of surgery it is probably that of the abdomen which is most facilitated by a stable level of profound muscle relaxation. ${ }^{1}$ To obtain this profound level of relaxation, in the absence of objective monitoring, the most commonly used technique is the injection of repeated doses of curarizing drugs as required by clinical observation.

Large doses of these drugs to satisfy subjectively the needs of the surgeon often require the use of decurarizing agents. ${ }^{2}$ This may be followed by side-effects, which are usually not serious, ${ }^{3,4}$ but the occurrence of some dramatic situation cannot be guaranteed. ${ }^{5}$ Others have reported that stable and predetermined levels of relaxation can be realized rapidly with the use of a bolus injection followed by a continuous

A.A. d'Hollander, M.D., R. Czerucki, M.D., A. Deville, M.D., F. Cuvelier, M.D., Department of Anaesthesiology, Brugmann Hospital, Place A. Van Gehuchten, 4, B-1020 Brussels, Belgium.

Can. Anaesth. Soc. J., vol. 29, no. 2, March 1982 infusion. ${ }^{6,7}$ If the relaxant used for infusion has a relatively short-lasting action and does not possess marked cumulative effects, a reduction in the use of decurarizing agents can be expected. According to preliminary studies the new steroid relaxant ORG NC45 would appear to have these properties. ORG NC45 is a monoquaternary analogue of pancuronium, in which the methyl group of the $2 \beta$ nitrogen atom is lacking (see Figure 1). This molecule is of the same order of potency as pancuronium for production of neuromuscular block in anaesthetized animals ${ }^{8}$ and man. ${ }^{9}$ Nevertheless, ORG NC45 appears to possess distinct advantages over pancuronium. Neuromuscular block with ORG NC45 develops and wears off more rapidly than that produced by comparably effective doses of pancuronium. ${ }^{8,9}$ Initial studies of ORG NC45 pharmacokinetics in man have demonstrated that the calculated distribution and elimination half lives, 4 and $31 \mathrm{~min}$ respectively, were both substantially shorter than those reported previously for pancuronium. ${ }^{10}$ 


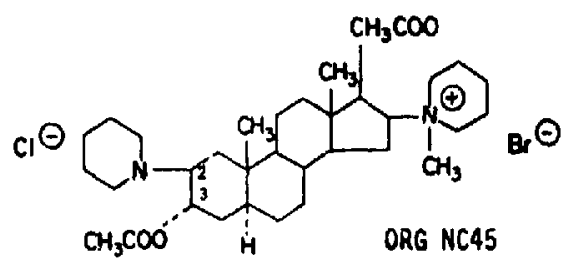<smiles>CO[C@H]1CC2CCC3C(CCC4(C)C(C)C([N+]5(C)CCCCC5)CC34)C2(C)CC1(N(C)C(C)=O)N(C)c1ccccc1</smiles>

Figure 1 Structures of ORG NC45 and pancuronium.

As with pancuronium, ORG NC45 is eliminated in part by liver and kidney, but inactivation of the parent molecule to less active metabolites presumably takes place directly in the plasma. ${ }^{11}$ An important and clear cut difference between ORG NC45 and most other non-depolarizing blocking agents is the relative lack of cumulation of ORG NC45 when successive doses ${ }^{9.12}$ or infusion ${ }^{9,13}$ are administered.

The object of this study was to assess the usefulness of this new drug, as well as the method of administration, during abdominal operations on adult patients.

\section{METHODS}

Twenty adult patients (ASA class I and II) scheduled for elective abdominal operations were studied. All have given informed consent. None had clinical or biochemical evidence of hepatic or renal cell damage. All patients were given diazepam $10 \mathrm{mg}$ orally one hour before anaesthesia.

Before induction of anaesthesia a displacement transducer (UC3 cell Statham), fitted with a tension attenuator (UL4-20 Statham) and incorporated in a hand-grip, was secured with adhesive strips to the left hand of the patient to measure isometric thumb displacement.

Anaesthesia was induced with intravenous methohexitone $1 \mathrm{mg} \cdot \mathrm{kg}^{-1}$ and fentanyl 5 $\mu \mathrm{g} \cdot \mathrm{kg}^{-1}$. Once the patient was unconscious, ventilation was controlled manually with equal volumes of nitrous oxide and oxygen by a circle circuit. Mechanical activity of the adductor pollicis was induced by square-wave pulses of
$0.1 \mathrm{~Hz}$ frequency and $0.2 \mathrm{msec}$ duration, delivered from a Grass $\$ 88$ stimulator through two 25-gauge thin-walled needles placed subcutaneously at the wrist, close the ulnar nerve.

The stimulation voltage was 1.5 times the level required to evoke a maximal twitch response. The resulting analog signals were amplified and registered on a polygraph recorder. When a consistent control tension had been achieved a bolus of ORG NC45 $0.07 \mathrm{mg} \cdot \mathrm{kg}^{-1}$ was injected. The trachea was intubated by the same anaesthetist once the adductor pollicis twitch height level had declined to less than 20 per cent.

Intubating conditions were assessed using the scoring system described by Krieg, et al. ${ }^{14}$ Thereafter ventilation was controlled mechanically with nitrous oxide oxygen $2: 1$ until the end of the operation. The level of ventilation was adjusted to provide normocapnoea with end tidal carbon dioxide about $5.3 \pm 0.1$ per cent (Datascope 500 carbon dioxide analyzer) or $\mathrm{Pa}_{\mathrm{Ca}_{2}}$ between 4.80 and $5.60 \mathrm{kPa}$ (Coming, 175). Supplemental doses of fentanyl were given when there were clinical signs of inadequate analgesia. Twitch height was maintained constant at 10 per cent of its initial control value by adjusting manually the flow of a Harvard syringe containing ORG NC45 $160 \mu \mathrm{g} \cdot \mathrm{ml}^{-1}$ in saline. Heat loss from the body core and exposed left arm was reduced by the use of a water-warming mattress with autoregulation $\left(37^{\circ} \mathrm{C}\right.$ rectal temperature) and by surgical sheets.

The following parameters were measured to assess the early neuromuscular effects of ORG NC45: the onset time: the time from the start of injection to the first depressed twitch height recording; the peak time: the time from the start of injection to the maximal decrease of twitch height; the peak effect; the maximum depression of twitch height expressed as a percentage of its base-line value.

The ORG NC45 requirements were calculated every ten minutes by measuring the displacement of the piston of the syringe during this period and expressed as $\mu \mathrm{g} / \mathrm{M}^{2} \mathrm{BSA} / 10 \mathrm{~min}$.

The infusion was stopped as soon as the surgical procedure permitted it.

During the recovery period following stopping of the ORG NC45 infusion the time required for recovery of the twitch height from 10 to 25 per cent and from 25 to 75 per cent was recorded. When the twitch height had recovered to 75 per cent the thenar mechanical responses to train of four $(2 \mathrm{~Hz}, 2$ seconds duration) and 
TABLE I

\begin{tabular}{|c|c|c|c|c|c|c|c|}
\hline No. & Sex & $\begin{array}{l}\text { Height } \\
(\mathrm{cm})\end{array}$ & $\begin{array}{l}\text { Weight } \\
(\mathrm{kg})\end{array}$ & $\begin{array}{c}\text { Age } \\
\text { (years) }\end{array}$ & Operation & $\begin{array}{l}\text { Duration of } \\
\text { Infusion (min) }\end{array}$ & $\begin{array}{l}\text { Total dose } \\
\text { (mg) }\end{array}$ \\
\hline 1 & $\mathrm{~F}$ & 160 & 50 & 34 & Cholecystectomy & 110 & 6.95 \\
\hline 2 & $\mathrm{~F}$ & 160 & 58 & 24 & Cholecystectomy & 70 & 13.64 \\
\hline 3 & $\mathbf{M}$ & 160 & 60 & 40 & Cholecystectomy & 80 & 9.68 \\
\hline 4 & $\mathrm{~F}$ & 146 & 76 & 64 & Gastrectomy & 170 & 13.02 \\
\hline 5 & $M$ & 162 & 59 & 65 & Incisional Hemia & 90 & 10.26 \\
\hline 6 & $\mathrm{~F}$ & 164 & 61 & 60 & Left Colectomy & 130 & 8.13 \\
\hline 7 & $\mathrm{~F}$ & 175 & 75 & 56 & Cholecystectomy & 110 & 12.03 \\
\hline 8 & $\mathbf{M}$ & 180 & 84 & 60 & Inguinal Hernia & 80 & 8.59 \\
\hline 9 & $\mathbf{F}$ & 159 & 55 & 60 & $\begin{array}{l}\text { Sigmoidectomy + } \\
\text { Cholecystectomy }\end{array}$ & 140 & 13.68 \\
\hline 10 & $\mathbf{F}$ & 160 & 48 & 66 & Cholecystectomy & 100 & 11.02 \\
\hline 11 & $\mathrm{~F}$ & 162 & 65 & 64 & Cholecystectomy & 130 & 8.26 \\
\hline 12 & $\mathrm{~F}$ & 172 & 68 & 70 & Cholecystectomy & 80 & 6.13 \\
\hline 13 & $\mathrm{~F}$ & 175 & 77 & 85 & Left Colectomy & 90 & 5.91 \\
\hline 14 & $\mathbf{M}$ & 168 & 86 & 36 & Umbilical Hernia & 60 & 11.42 \\
\hline 15 & $\mathrm{~F}$ & 150 & 42 & 65 & Cholecystectomy & 90 & 4.59 \\
\hline 16 & $\mathbf{M}$ & 177 & 68 & 26 & Gastrectomy & 150 & 20.99 \\
\hline 17 & $\mathrm{~F}$ & 166 & 67 & 51 & Cholecystectomy & 80 & 9.35 \\
\hline 18 & $F$ & 165 & 71 & 46 & Cholecystectomy & 100 & 10.93 \\
\hline 19 & $\mathrm{M}$ & 170 & 70 & 76 & Left Colostomy & 120 & 9.77 \\
\hline 20 & $\mathbf{F}$ & 164 & 65 & 53 & Cholecystectomy & 90 & 11.25 \\
\hline Mean & 149 & 165.75 & 65.25 & 55.05 & & 103 & 10.28 \\
\hline SEM & 68 & \pm 1.91 & \pm 2.57 & \pm 3.64 & & \pm 6 & \pm .80 \\
\hline
\end{tabular}

tetanic fade $(50 \mathrm{~Hz}, 5$ seconds duration) stimulations were also recorded.

When necessary, levallorphan $0.5 \mathrm{mg}$ was given intravenously every minute until the respiratory rate exceeded 10 breaths per minute. Following skin closure and the dressing of the wound, spontaneous respiration was manually assisted with 100 per cent oxygen until the cough reflex had returned. The trachea was then extubated.

Spontaneous muscular activity was tested by asking patients to open their eyes widely, put out the tongue and grip the anaesthetist's hand. Patients were then taken to the recovery room for clinical observation and detection of any recurarization.

\section{RESULTS}

Clinical details of the patients investigated are summarized in Table I.

The neuromuscular effects of ORG NC45 during the onset of paralysis were characterized by onset time of $70 \pm 5 \mathrm{sec}$, peak effect time of $400 \pm 24 \mathrm{sec}$ and a peak effect of $7 \pm 1$ per cent of the initial twitch height.

The time elapsing between injection of ORG NC45 and tracheal intubation at a time when the twitch height had become depressed below 20 per cent of controls was $235 \pm 21 \mathrm{sec}$. In all cases laryngoscopy was possible without difficulty. Intubating conditions according to the criteria established by Krieg, et al. ${ }^{14}$ were "good" (slight movement of vocal cords and diaphragm) in six patients and "excellent" (no coughing, open vocal cords) in fourteen patients.

The ORG NC45 requirements varied with time (see Figure 2), but were generally stabilized after one half hour at about $225 \pm 35 \mu \mathrm{g} / \mathrm{M}^{2}$ BSA/10 min (Table II).

During the infusion period the degree of abdominal relaxation achieved with an adductor pollicis twitch height reduction to 10 per cent of its initial value was uniformly judged as adequate to excellent by the surgeons.

The duration of ORG NC45 perfusion was $103 \pm 6 \mathrm{~min}$; the total dosage used was $10.28 \pm$ $0.80 \mathrm{mg}$ (Table I). Recovery times following the end of the ORG NC45 infusion were $10.5 \pm 1$ and $26.8 \pm 4.5 \mathrm{~min}$ for twitch height reductions of $10-25$ and $25-75$ per cent respectively.

At 75 per cent recovery level, the train of four on stimulation with $2 \mathrm{~Hz}$ reached $44.5 \pm 4.5 \mathrm{per}$ cent (range: $22-78$ ) and the tetanic fade at $50 \mathrm{~Hz}$ and over 5 sec gained $75 \pm 8$ per cent (range: 17-100). (Table III).

All patients awoke rapidly after the end of the administration of nitrous oxide. All were able to 
TABLE II

Characteristics of Onset and Maintenance of a Fixed Twitch Height

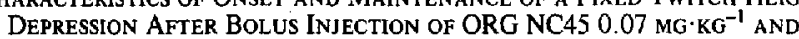
DEMAND INFUSION

\begin{tabular}{lccc}
\hline \hline & Mean & SEM & Range \\
\hline Onset Time (sec) & 70 & 5 & $40-110$ \\
*Intubation Latency (sec) & 235 & 21 & $110-390$ \\
Peak Effect Time (sec) & 400 & 24 & $240-600$ \\
Peak Effect $(\%$ initial value) & 7 & 1 & $2-15$ \\
†ORG NC45 $\left(\mu \mathrm{g} / \mathrm{BSA} \mathrm{m}^{2} / 10 \mathrm{~min}\right)$ & 225 & 35 & $44-483$ \\
\hline
\end{tabular}

*Twitch height below 20 per cent of initial value.

tThis parameter was calculated for each patient by considering only the quantity of ORG NC45 administered after the 30th minute following initial bolus relaxant administration.

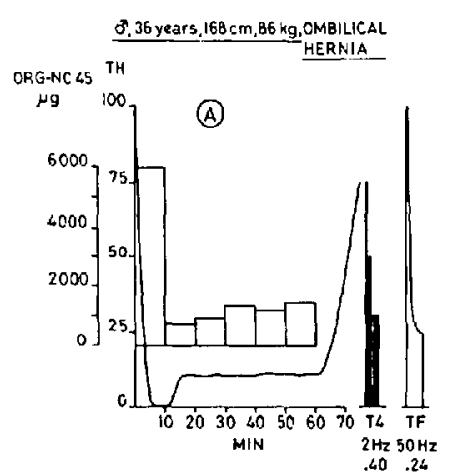

J.40 years, $160 \mathrm{~cm}, 60 \mathrm{~kg}$.CHOLECYSTECTOMY

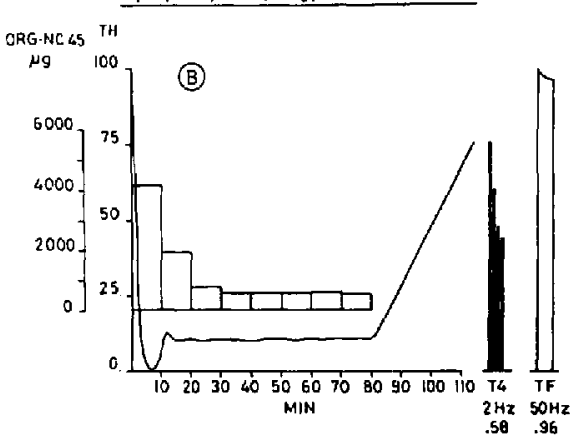

Figure 2 Progression of ORG NC45 requirements during 10 minute periods illustrated along with the changing muscle activity in two patients. Train of four $(\mathrm{T} 4 ; 2 \mathrm{~Hz}$ ) and tetanic fade (TF; $50 \mathrm{~Hz}-5 \mathrm{sec})$ were performed once twitch height $(\mathrm{TH} ; 0.1 \mathrm{~Hz})$ had gained a value of 75 per cent of its initial value.

protrude their tongues, open their eyes widely and grip the hand of the anaesthetist for at least $5 \mathrm{sec}$ if they were asked to do so. Muscular response fade was clinically detectable in several patients.
TABLE III

Characteristics of Twitch Height Recovery Rates, Train of Four and Tetanic Fade After TERMINATION OF ORG NC45 Infusion

\begin{tabular}{llcc}
\hline & Mean & SEM & Range \\
\hline TH 10-25 min & 10.5 & 1 & $4-22$ \\
TH 25-75 min & 26.8 & 4.5 & $3-82$ \\
Train of Four* \% & 44.5 & 4.5 & $22-78$ \\
$\begin{array}{l}2 \mathrm{~Hz} \\
\text { Tetanic fade* \% }\end{array}$ & 75 & 8 & $17-100$ \\
$\quad 50 \mathrm{~Hz}, 5 \mathrm{sec}$ & 75 & & \\
\hline & TH = twitch height. \\
*These tests were performed once TH reached a \\
recovery level of 75 per cent of its initial value.
\end{tabular}

In the group studied, only two patients needed to be reversed with atropine $0.75 \mathrm{mg}$ and neostigmine $1 \mathrm{mg}$ because clinical observation of respiratory movement and the hand grip test appeared subjectively inadequate. Their value of train of four $(2 \mathrm{~Hz})$ and tetanic fade $(50 \mathrm{~Hz}$, $5 \mathrm{sec}$ ), done at the 75 per cent twitch height level were 22 and 27 per cent for one and 22 and 24 per cent for the other patient, respectively.

Subjectively, no strict correlation was found between electrically elicited tetanic fade and the five second hand-grip test; this last test requiring spontaneous muscular activity always appeared less sustained than the electrical one.

No cases of clinical recurarization were observed during the period in the recovery room. The hand-grip tested at fifteen minute intervals improved both in force and in fade reduction in all patients. Generally, fade was not evident after the second hand-grip test in the recovery room.

\section{Discussion}

As determined by Ali and Savarese, ${ }^{15}$ the nerve stimulation rate of $0.1 \mathrm{~Hz}$ appears appro- 
priate for routine monitoring because the 10 per cent residual twitch height signal is still well defined using the classical displacement transducer method and acceptable intubation conditions can be reached without abolishing the twitch height signal. In this study, the tracheal intubation was carried out at a 20 per cent residual twitch height. With bolus administration of ORG NC45 $0.07 \mathrm{mg} \cdot \mathrm{kg}^{-1}$, this level was reached at about the fourth minute after injection. At that time laryngoscopy was always easy, but moderate bucking was still present in about one third of the patients. To achieve the best intubation conditions, with no movement of the vocal cords and no reflex coughing, a dose of ORG NC45 $0.08 \mathrm{mg} \cdot \mathrm{kg}^{-1}$ or more would appear to be the more appropriate. ${ }^{9}$

This study shows that even in the absence of a halogenated vapour, 10 per cent of the residual mechanical power of the adductor pollicis stimulated at $0.1 \mathrm{~Hz}$ frequency is uniformly accompanied by adequate relaxation of the abdominal wall as estimated by the surgeons. Our results agree with the conclusions from previous studies ${ }^{1,16}$ with different regimens of anaesthetic drugs. As illustrated by Figure 2, the ORG NC45 requirement generally reached a stable level after the thirtieth minute following administration of the loading bolus. However, the steady state dosage requirement varied widely from patient to patient, ranging from 44 to $483 \mu \mathrm{g}$ ORG NC45/M ${ }^{2}$ BSA $/ 10$ min (Table II). Such large variations of ORG NC45 requirements were observed previously in the pilot study of ORG NC45 by Agoston, et al. ${ }^{9}$ under clinical conditions very similar to ours.

The large individual variations make it difficult to predict the optimal perfusion rate of ORG NC45 needed to maintain a stable 10 per cent residual twitch height paralysis in a given patient. The best way to determine the individual relaxant requirement with any precision is to use a monitoring method. The use of such a control system would appear to be particularly necessary, as changes in the degree of relaxation with ORG NC45 can occasionally be very rapid, as illustrated in Figure 1, Graph A. With monitoring, long-lasting ORG NC45 infusion was followed by only minor recovery problems; but there were wide variations in rate of recovery from paralysis, which varied from three to 83 minutes for a twitch height of 25 to 75 per cent. Observations of our patients after awakening show that extubation of the trachea at a twitch height slightly above 75 per cent of control is satisfactory to provide sufficiently deep breath- ing in the absence of central narcotic depression. This observation, made after a vapour-free anaesthesia, tallies with previous data showing that in anaesthetized patients or in conscious volunteers slight partial paralysis of hand muscles is not accompanied by a marked decrease in the power of the respiratory muscles. ${ }^{17-22} \mathrm{At}$ 75 per cent twitch height recovery, the train of four and the tetanic fade showed large variations, ranging from 22 to 78 per cent and from 17 to 100 per cent respectively. These wide variations, independent of the recovery rate of the twitch height, do not permit the determination of precise train of four and tetanic fade values equivalent to the 75 per cent twitch height level. This is clear by comparison of Graphs $A$ and $B$ in Figure 1 under the conditions of this study; that is, in the absence of a halogenated vapour, low frequency of nerve-stimulation and ASA class I-II patients. Values above 45 and 75 per cent for train of four and tetanic fade appeared to be suitable levels to provide muscular activity compatible with acceptable extubation conditions for the majority of patients. Mogensen and coll. ${ }^{23}$ studying residual curarization in the recovery room have reported that sustained head-lift can be observed even at 50 per cent train of four recovery. Nevertheless it seems obvious that the integrity of respiratory muscle function can be guaranteed only for higher values of train of four. ${ }^{24}$

In conclusion, bolus loading and monitored demand infusion of ORG NC45 appears suitable for the production of stable muscle relaxation during abdominal operations. Even after longlasting infusion, no major problems were encountered during the recovery period. This procedure can be recommended for general use, but because of the wide variations of ORG NC45 dosage requirements the provision of a monitoring system is imperative to prevent overdosage.

\section{ACKNOWLEDGEMENTS}

We thank Dr S. Denton for assistance in reviewing the manuscript and Ms Van Herrewegen for secretarial help. This work was performed under contract of the Ministère de la Politique Scientifique (Actions concertées).

\section{REFERENCES}

1. DE JONG, R.H. Controlled relaxation. I. Quantification of electromyogram with abdominal relaxation. J.A.M.A. 197: 113 (1966).

2. MiLleR, R.D. Antagonism of neuromuscular blockade. Anesthesiology 44: 318 (1976). 
3. KJellberG, M. \& Tammisto, T. Heart rate changes after atropine and neostigmine given for the reversal of muscle paralysis. Acta Anaesth. Scand. 14: 203 (1970).

4. ROSNER, V., KEPES, E.R. \& FoldEs, F.F. The effects of atropine and neostigmine on heart rate and rhythm. Brit. J. Anaesth. 43: 1066 (1971).

5. POOLER, H.E. Atropine, neostigmine and sudden deaths. Anesthesia 12: 198 (1957).

6. Somogyi, A.A., Shanks, C.A. \& Triggs, E.J. Combined i.v. bolus and infusion of pancuronium bromide. Br. J. Anaesth. 50: 575 (1978).

7. Ramzan, M.I., Shanks, C.A. \& Triggs, E.J. Pharmacokinetics of tubocurarine administered by combined i.v. bolus and infusion. Br. J. Anaesth. 52: 893 (1980).

8. Marshall, I.G., Agoston, S., Boordu, L.H., DURANT, N.N. \& FoldES, F.F. Pharmacology of ORG NC45 compared with other non depolarizing neuromuscular blocking drugs. $\mathrm{Br}$. J. Anaesth. 52: suppl. 1, 11 (1980).

9. Agoston, S. , SAlt, P., Newton, D., Bencini, A., Boomsma, P. \& ErdmanN, W. The neuromuscular blocking action of ORG NC45, a new pancuronium derivative in anaesthetized patients. Br. J. Anaesth. 52: suppl. 1, 53 (1980).

10. VAN DER VEEN, F. \& BENCINI, A. Pharmacokinetics and pharmacodynamics of ORG NC45 in man. Br. J. Anaesth. 52: suppl. 1, 37 (1980).

11. Savage, D.S., Sleigh, T. \& Carlyle, I. The emergence of ORG NC45 $1[(2 \beta, 3 \alpha, 5 \alpha, 16 \beta$, $17 \beta)-3, \quad 17-b i s$ (acetyloxy)-2-(1-piperidinyl)androstan-16yl]-1-methylpiperidinium bromide, from the pancuronium series. Br. J. Anaesth. 52: suppl. 1, 3 (1980)

12. FAHEY, M.R., Morris, R.B., Miller, R.D., Sohn, Y.J., Cronnelly, R. \& GenCareli.I, Z. Clinical pharmacology of ORG NC45 (Norcuron $^{\mathrm{TM}}$ ): a new nondepolarizing muscle relaxant. Anesthesiology 55:1 (1981).

13. D'Hollander, A.A., Massaux, F., NevelSTEEN, M. \& AGoston, S. Age-dependent dose response relationship of ORG NC45 in anaesthetized patient. Brit. J. Anaesth. (in press).
14. Krieg, N., Mazur, L., Booidj, L.H. \& Crul, J.F. Intubation conditions and reversibility of a new non-depolarizing neuromuscular blocking agent, ORG NC45. Acta Anaesth. Scand. 24: $423(1980)$

15. Ali, H.H. \& Savarese, J.J. Stimulus frequency and dose-response curve to d-tubocurarine in man. Anesthesiology 52: 36 (1980).

16. Usubiaga, J.E. \& MoYA, F. The clinical use of a new nerve stimulator. Acta Anaesth. Scand. 11: 15 (1967)

17. Foldes, F., Monte, A.P., Brunn, H.M. \& WOLFSON, B. The influence of exercise on the neuromuscular activity of relaxant drugs. Can. Anaesth. Soc. J. 8: 118 (1961).

18. Johansen, S.H., Jorgensen, P. \& Molbech, $\mathrm{S}$. Effect of tubocurarine on respiratory and non respiratory muscle power in man. J. Appl. Physiol. 19: 990 (1964).

19. WALTS, L.F., LEYIN, N. \& Dillon, J.B. Assessment of recovery from curare. J.A.M.A. 231: 1894 (1970).

20. RigG, J.R., ENGel, L.A. \& Ritchie, B.C. The ventilatory carbon dioxide during partial paralysis with tubocurarine. Br. J. Anaesth, 42: 105 (1970).

21. Wymore, M.L. \& Fisele, J.H. Differential effects of d-tubocurarine on inspiratory muscles and two peripheral muscle groups in anesthetized man. Anesthesiology 48: 360 (1978).

22. GAL, T.J. \& GoldBerG, S.K. Relationship between respiratory muscle strength and vital capacity during partial curarization in awake subjects. Anesthesiology 54: 141 (1981).

23. VIBY-MOGENSEN, J., JORGENSEN, B.D. \& ORDING, H. Residual curarisation in the recovery room. Anesthesiology 50: 539 (1979).

24. Ali, H.H., Wilson, R.S., Savarese, J.J. \& KITZ, R.J. The effect of tubocurarine on in directly elicited train of four muscle response and respiratory measurements in humans. Br. J. Anaesth. 47: 570 (1975).

\section{RÉsumé}

Afin d'obtenir un relâchement musculaire stable et suffisant au cours d'interventions intra-abdominales, les auteurs ont utilisé chez 20 patients anesthésiés (methohexital, fentanyl, $\mathrm{N}_{2} \mathrm{O}$ ) une perfusion continue à la demande d'ORG NC45 mise en route après une dose de charge de $0.07 \mathrm{mg} \cdot \mathrm{kg}^{-1}$. La vitesse de perfusion du ORG NC45 a été réglée de manière à maintenir une réponse musculaire mécanique mesuréc au niveau de l'adducteur du pouce après stimulation supra-maximale du nerf cubital égal à 10 pour cent du niveau de départ. Le relâchement ainsi obtenu, a toujours satisfait les opérateurs. En cours d'intervention, les besoins en curares diminuèrent progressivement pour devenir stables au bout d'une demi-heure. Néanmoins, en régime stable, les variations individuelles furent très importantes: $44-483 \mathrm{~g} / \mathrm{m}^{2}$ BSA $/ 10$ min-moyenne: $225 \mathrm{~g} / \mathrm{m}^{2}$ BSA $/ 10 \mathrm{~min}$. La durée de la perfusion a varié de 60 à $170 \mathrm{~min}$-moyenne: $103 \mathrm{~min}$. Après l'arrêt de la perfusion d'ORG NC45, le temps mis par les patients pour récuperer, à partir de 25 pour cent un single twitch à 75 pour cent, fut de 3 à $82 \mathrm{~min}$-moyenne $27 \mathrm{~min}$. Le réveil des patients organisé après le passage du single twitch à 75 pour cent fut rapide après la suppression du protoxyde d'azote. Aucun signe de recurarisation ne fut observé dans la série êtudiée.

En conclusion, ce mode d'administration de l'ORG NC45 permet d'assurer un niveau stable de curarisation sans provoquer de problèmes particuliers par la suite. Néanmoins, du fait de la grand susceptibilité individuelle observée, ce mode d'administration de l'ORG NC45 requiert le contrôle de la curarisation par un monitoring objectif afin d'éviter d'éventuels surdosages. 